\title{
Reproductive Biology of little tunny, Euthynnus alletteratus (Rafinesque 1810) in the Eastern Coast of Alexandria, Egypt
}

\author{
Hussain Mohamed, Alaa Eldin El-Haweet* and Essam Sabry \\ Arab Academy for Science and Technology \& Maritime Transport, Alexandria, Egypt. \\ E-mail: el_haweet@yahoo.com , alaaelhaweet@aast.edu;
}

\section{ABSTRACT}

Reproductive biology of Euthynnus alletteratus was described based on 628 fishes that were collected from Abu Qir landing site between October 2006 and September 2007. Only 146 specimens were sexually distinguished (102 females, 44 males) and the others were immature. The sex ratio was estimated as M: F 1:2.3. Size at first sexual maturity was estimated as $42 \mathrm{~cm}$. Spawning season was investigated based on monthly observation of gonadal maturity stages and gonad-somatic index (GSI). The spawning season extends from June to August with a highest GSI value in June.The fork length (FL)-gutted weight (GW) relationship was estimated as $\mathrm{GW}=0.052 \mathrm{FL}^{2.639}$ for combined sexes. Condition factor $(\mathrm{K})$ was calculated using the gutted weight of all samples (regardless of sex) with an average of 1.3. Management plan is important to overcome the high percentage of immature fishes in the catch off Alexandria water. Extending closed season to July and increasing the length at capture to $44 \mathrm{~cm}$ are important for enhancing the chance of spawning at least once during its life.

Keywords: Euthynnus alletteratus, reproduction, spawning season, condition factor, Alexandria, Egypt

\section{INTRODUCTION}

Little tunny or Euthynnus alletteratus is a pelagic species; one of the members of the Scombridae, has a wide distribution in the world and predominant in the Mediterranean Sea and black sea (Belloc, 1955; Valeiras and Abad, 2007). It is occurred in the Mediterranean catch all over the year but with more abundant during summer months (Sylva and Rathjen, 1961). Egyptian Mediterranean catch from E. alletteratus was fluctuated between 704 and 1442 tonnes in the period from 1998 to 2007 (GAFRD, 2008).

Some Biological studies on E. alletteratus have been conducted in different regions of Mediterranean Sea, e.g. in Turkey (Kahraman and Alicli, 2007), in Spain (Macias et al., 2006), in Tunisia (Hajjej et al., 2010), in Eastern Atlantic Ocean (Gaykov and Bokhanov, 2008). They focused on length weight relationship, sex ratio, maturity stages, length at first sexual maturity, spawning season and gonad-somatic index. No reproductive study about E. alletteratus was conducted in Egypt. Results of such study could be used for stock assessment and fishery management of this important species (Hajjej et al., 2010).

So, the present study deals with the reproductive biology of $E$. alletteratus in the Eastern Coast of Mediterranean Sea, off Alexandria, Egypt.

\section{MATERIALS AND METHODS}

Samples of E. alletteratus were collected weekly during the period from October 2006 to September 2007 from Abu Qir landing site, off eastern coast of 
Alexandria city (Fig. 1); closed season was applied from $1^{\text {st }}$ May until $15^{\text {th }}$ June. Total of 628 specimens were collected from commercial fishery using gill net. In laboratory fork length were measured to the nearest $1 \mathrm{~mm}$ and gutted weight to the nearest $1 \mathrm{~g}$, while gonad weight to the nearest $0.01 \mathrm{~g}$. Sex was identified visually after dissecting. Sex ratio was calculated according to the number of males to females.

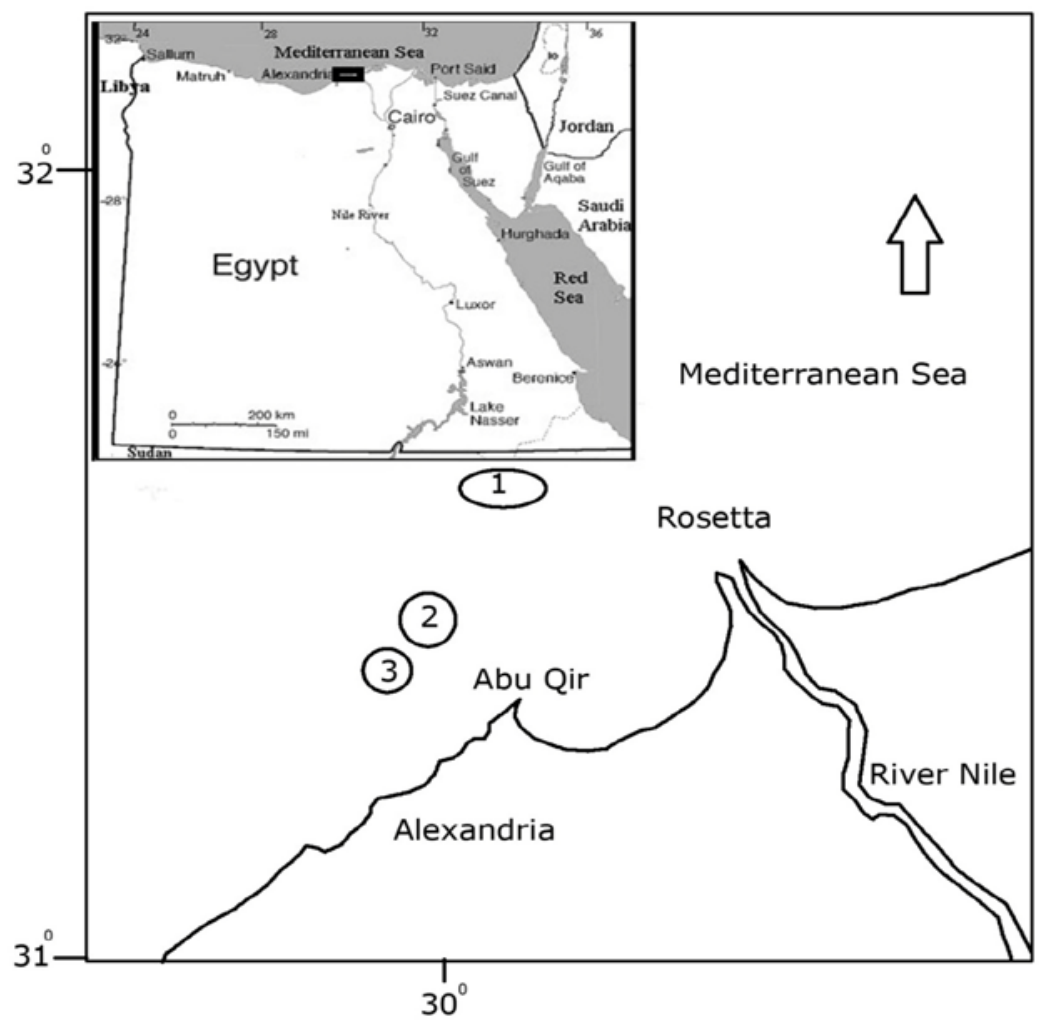

Fig.1: Eastern Coast of Alexandria city, Egypt, (black circles indicate the fishing ground and Abu Qir is the landing site)

Maturity stages of E. alletteratus gonads were identified based on morphological changes that take place during its development to reach spawning. Maturity stages were observed by gonad coloring and its volume percentage to the body cavity. Six stages were identified; I is immature, II is mature, III is maturing, IV is ripe, V is spawning and VI is spent (Nickolsky, 1963). Length at first maturity which $50 \%$ of fish were sexually mature (Pitt, 1970) .was estimated for reproductively active fish (Stages III-VI).

Gonad-Somatic Index (GSI) was calculated to determine spawning season according to Shelly \& Southgate (1988) formula as following:

$$
\text { GSI }=(\mathrm{G} / \mathrm{GW}) * 100
$$

Where: $\mathbf{G}$ is Gonads weight (g) and $\mathbf{G W}$ is gutted weight (g).

The relationship between Gutted weight (GW) and Fork length (FL) was expressed by Le Cren, (1951) equation:

$$
\mathrm{GW}=\mathrm{a} \mathrm{FL}{ }^{\mathrm{b}}
$$

Where: $\mathrm{a}=$ intercept and $\mathrm{b}=$ slop

The Fulton condition factor $(\mathbf{K})$ was calculated using gutted weight and fork length by the following formula:

$$
\mathbf{K}=\left(\mathbf{G W} / \mathbf{F L}^{3}\right) \mathbf{x} \mathbf{1 0 0} \text { (Le Cren, (1951) }
$$

Where: $\mathbf{G W}$ is the gutted weight (g) and FL is the fork length (cm). 


\section{RESULTS}

\section{Sex ratio:}

Only 146 fish of the entire sample could be identified by sex. Out of 628 sampled specimens, 483 fish were recorded as immature representing $77 \%$. The calculated sex ratio of collected mature samples was $\mathrm{M}: \mathrm{F}=1.0$ : 2.3. Females dominated of the smallest sizes from 32 to $73 \mathrm{~cm}$ FL and also largest lengths (90-95 $\mathrm{cm}$ ), while males dominated the lengths of $80 \mathrm{~cm}$ and lengths larger than $100 \mathrm{~cm}$ (Fig. 2). No mature fish were found in November and December. Females dominated the catch throughout the year. The highest percentage for females was found in June (60\%) and July (54\%) as shown in Fig. 3.

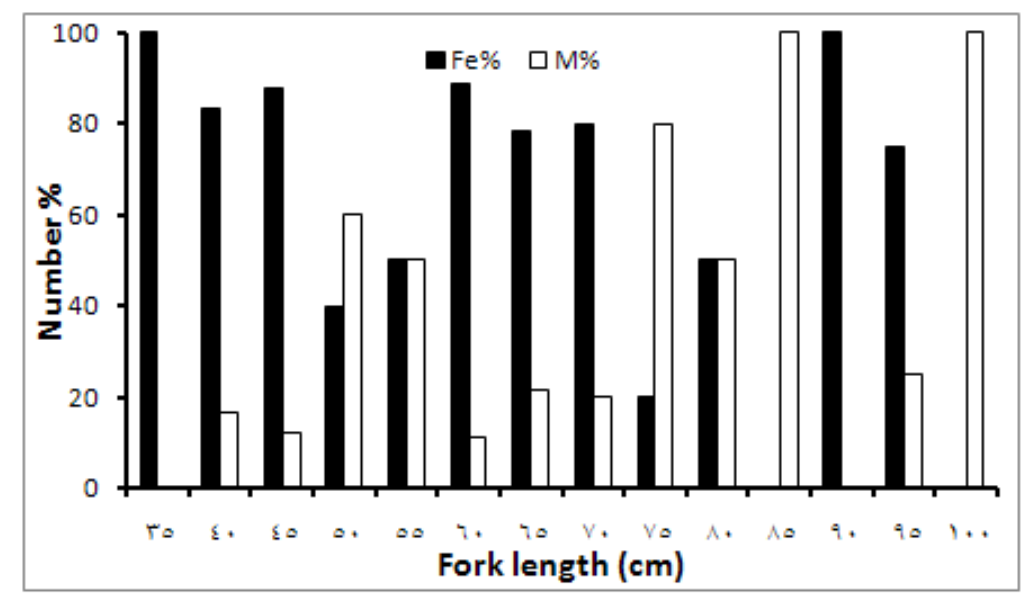

Fig. 2: Sex ratio by fork length for female and male of E. alletteratus in the Eastern Coast of Alexandria, Egypt.

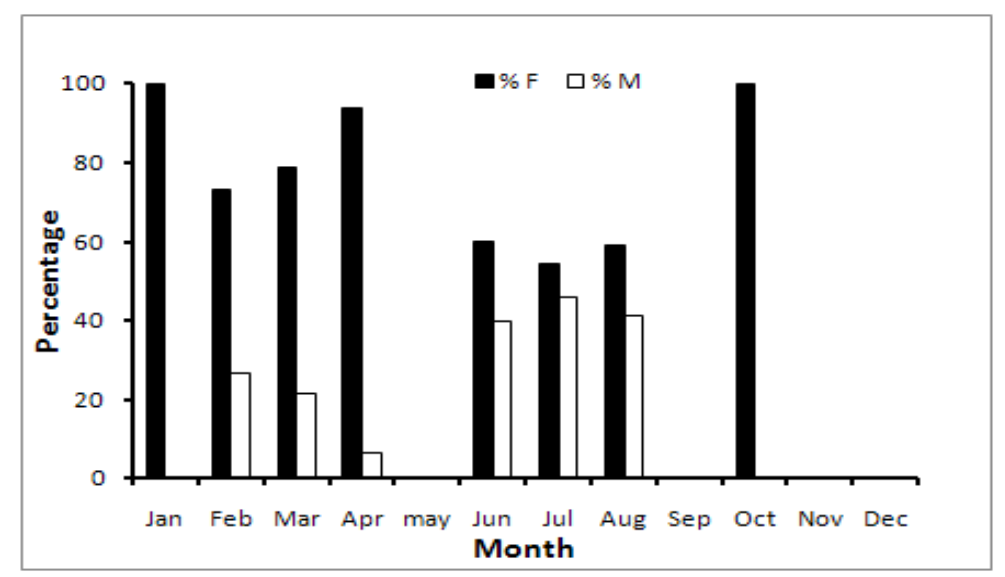

Fig. 3: Monthly variation in sex ratio of E. alletteratus in the Eastern Coast of Alexandria, Egypt.

\section{Maturity Stages}

Specimens of E. alletteratus from Eastern Coast of Alexandria were classified to immature and mature fishes. Immature fishes were absent in the catch during the period from June to August in which all samples were mature. Monthly pattern of gonadal activity showed occurrence of five maturity stages for females and males; from stage II up to stage VI (Fig. 4). For females, maturity stage II was dominated the catch from January to April and absent during spawning season, then appeared again in October. Maturity stage III was found from April to July and maturity stage IV from June, while maturity stages V and VI were occurred from June to August. For 
Males, maturity stage II was dominated the catch from January to April, while maturity stage III and IV were available in June and July. Stages V and VI occurred from June to August.
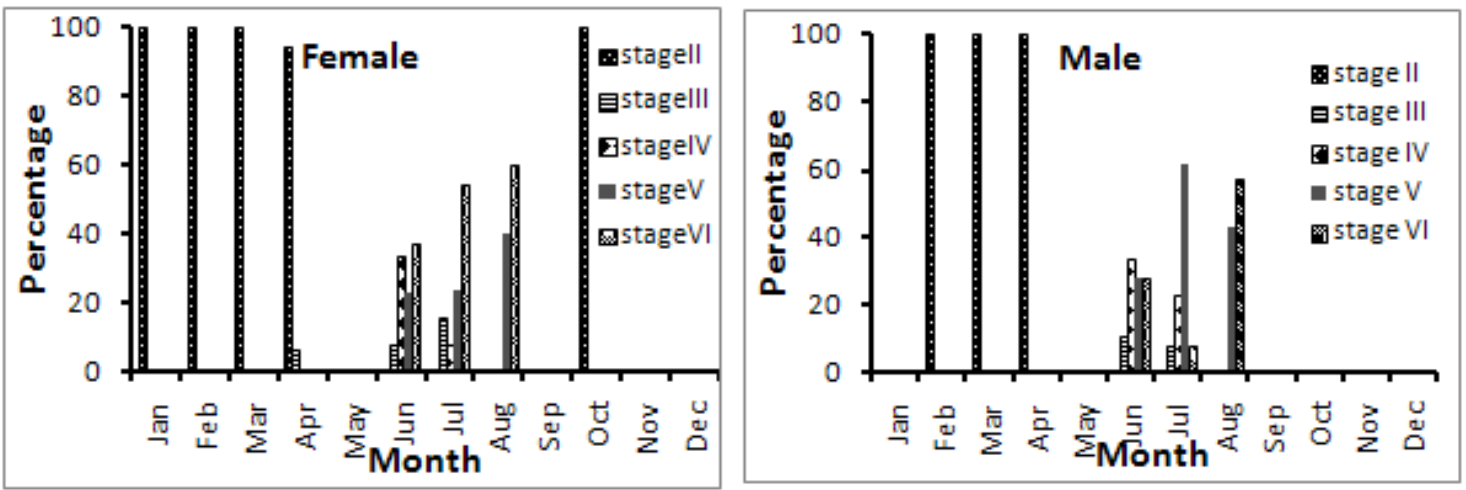

Fig. 4: Monthly changes of different maturity stagesfor female and male of E. alletteratus from Eastern Coast of Alexandria, Egypt.

\section{Length at first sexual maturity}

The length at first sexual maturity of E. alletteratus (50\% maturity) was estimated as $42 \mathrm{~cm}$ (Fig. 5). The smallest mature female and male was 33 and $38 \mathrm{~cm}$ respectively.

\section{Gonad-Somatic Index}

Gonad-Somatic Index (GSI) was calculated for females and males of $E$. alletteratus. In general, gonads were in dormant condition from September to December, so the GSI had no value. When the gonads started to be developed in January, the GSI value of females increased from 0.2 in January to 5 in June, reaching its peak then decreased gradually from July, while for males gonads started to develop in February and reach its peak in June (5.6), then afterward start to decrease. The results revealed that spawning season is restricted from June to August as shown in Fig. 6.

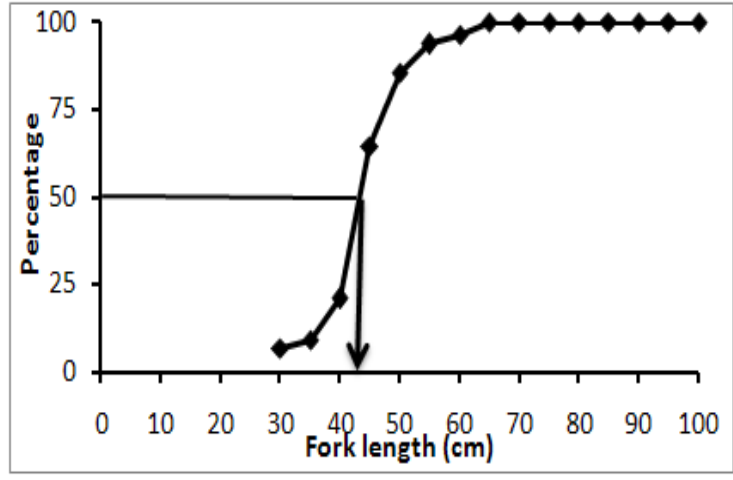

Fig. 5: Length at first Sexual maturity of $E$. alletteratus in the Eastern Coast of Mediterranean Sea off Alexandria, Egypt.

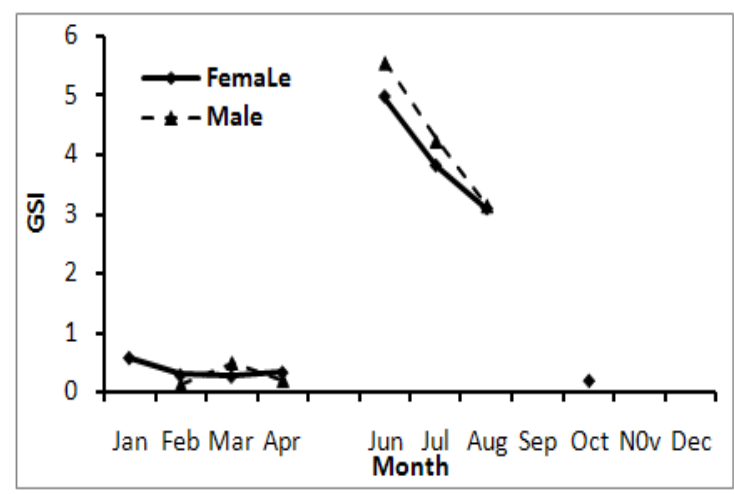

Fig. 6: Monthly variation of Gonad-somatic Index (GSI) of E. alletteratus from Eastern Coast of Alexandria, Egypt.

\section{Length weight relationship}

Length weight relationship of E. alletteratus was calculated for all mature samples (females and males). Fork length of females were ranged between 33 and $96 \mathrm{~cm}$ and their gutted weights ranged from 554 to $9000 \mathrm{~g}$., while males length varied 
between 38 and $102 \mathrm{~cm}$ and their weights varied between 782 and 11500g. Moreover, immature fork lengths ranged between 13 and $53 \mathrm{~cm}$ and their weights ranged between 16 and 1800g (Fig. 7). Length weight relationship equations were estimated as:

$\mathrm{GW}=0.052 \mathrm{FL}^{2.639} \quad\left(\mathrm{r}^{2}=0.981, \mathrm{n}=146\right)$ for combined sex

$\mathrm{GW}=0.060 \mathrm{FL}^{2.600} \quad\left(\mathrm{r}^{2}=0.980, \mathrm{n}=102\right)$ for females

$\mathrm{GW}=0.037 \mathrm{FL}^{2.722} \quad\left(\mathrm{r}^{2}=0.984, \mathrm{n}=44\right)$ for males

$\mathrm{GW}=0.008 \mathrm{FL}^{3.125} \quad\left(\mathrm{r}^{2}=0.988, \mathrm{n}=483\right)$ for immature samples
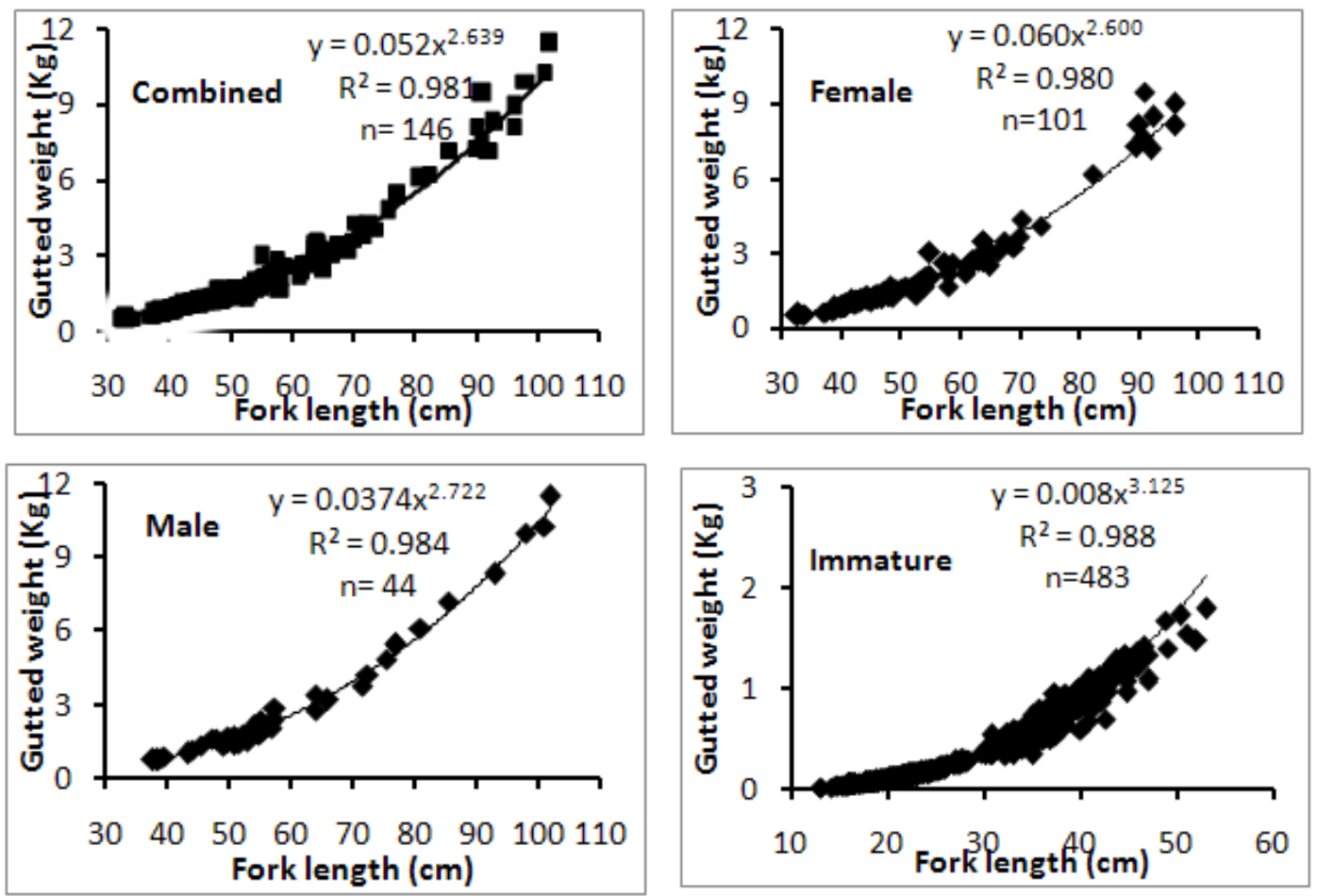

Fig. 7: Length weight relationship for combined sexes, females, males and immature of E. alletteratus in the Eastern Coast of Alexandria, Egypt.

\section{Condition factors}

The average condition factor $(\mathrm{K})$ of E. alletteratus was calculated using the gutted weight of all samples (regardless of sex) with value of 1.3 (Fig. 8).

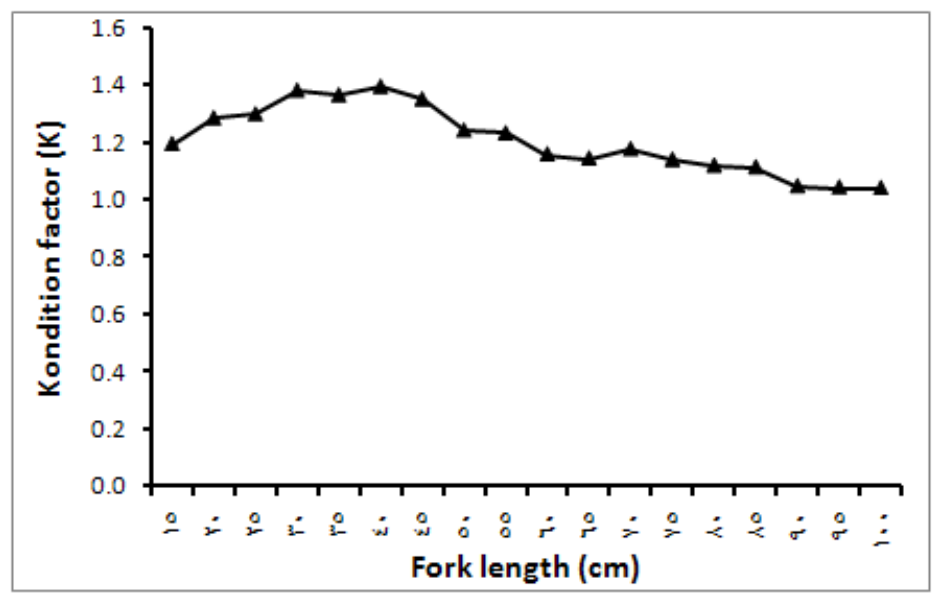

Fig. 8: Changes of condition factor (K) by length of E. alletteratus from Eastern Coast of Alexandria, Egypt. 
The condition factor was increasing with the increasing of fish length before $42 \mathrm{~cm}$ and then $\mathrm{K}$ value decreased with increasing the length. Monthly variation of condition factor showed lowest values in June and July (Table1).

Table 1: Months changes of condition factor (K) of E. alletteratus from Eastern Coast of Alexandria.

\begin{tabular}{|c|c|}
\hline Month & K \\
\hline Oct. & 1.324 \\
\hline Nov. & 1.361 \\
\hline Dec. & 1.384 \\
\hline Jan. & 1.344 \\
\hline Feb. & 1.365 \\
\hline Mar. & 1.343 \\
\hline Apr. & 1.388 \\
\hline June & 1.174 \\
\hline Jul. & 1.102 \\
\hline Aug. & 1.261 \\
\hline Sep. & 1.283 \\
\hline Average & 1.3 \\
\hline
\end{tabular}

\section{DISCUSSION}

Euthynnus alletteratus is a common pelagic species in Egyptian Mediterranean fisheries; the catch of E. alletteratus fluctuated between 704 to 1442 tonnes (GAFRD, 2008). The present study investigates the biological parameters of E. alletteratus for this important species in the Egyptian Mediterranean waters.

Reproduction is the process by which species are propagated. The success of any fish species is ultimately determined by the ability of its members to reproduce successfully in a fluctuating environment (Moyle and Czech, 2000). Sex ratio indicates the proportion of male and female in the population and is expected to be 1:1 in nature. Any deviation from this ratio may indicate the dominance of one sex over the other. This happens because of differential behavior of sexes, environmental conditions, fishing activities, etc. (Bal and Rao, 1984).Sex ratio in the present study for male to female was found to be 1.0:2.3 (i.e. females dominated males through the year).This means that there is a difference in availability of both sexes for fishery; this may be due to a spatial segregationof sexes or because of different behavior in relation to the gear (Mendonça et al., 2006).This result is closer to what reported by Kahraman et al. (2008) in Eastern Mediterranean, Valeiras et al. (2008) in Western Mediterranean and Hajjej et al.(2009) in Tunisia. This phenomenon was observed for other tuna species like Thunnus obesus (Nikaido et al. 1991), Thunnus thynnus (Clay 1991), Thunnus alalunga (Wu and Kuo1993; Ramon and Bailey1996), and Thunnus albacares (Sun et al., 2005). Circumstantial evidence suggests that the observed difference in sex ratio at size, is probably due to the possibility of different natural mortality rates, as suggested for swordfish in the North Atlantic Ocean by Restrepo et al. (1991).

Spawning in fish can be affected by several different environmental factors; temperature and photoperiod influence fish reproduction by stimulating sensory organs that induce the production of gonad hormones, which can induce physiological or behavioral responses (Junk, 1999). In the present study the monthly changes in the maturity stages for males and females indicated that the spawning period occurred between June and August. Monthly variation in mean Gonad-Somatic Index (GSI) of females and males confirmed the spawning season finding i.e. occurred between June and August. This agrees with what reported by Valeirasetal (2008) and Kaharaman et 
al. (2008) for western and eastern Mediterranean population respectively. RodriguezRoda, (1979) in southern Spain and off the coast of Senegal by Cayre and Diouf, (1983), Andaloro et al. (1998) in South Tyrrhenian and Sicily Strait, Hattour, (2000) and Hajjej et al. (2010) off Tunisia reported closer results. Oray and Karakulak, (2005) reported that spawning occurs only during June in East Mediterranean near Cyprus and Santamaria et al. (2005) reported that spawning occurs in July and August in South Italian seas. Landau (1965) showed that the spawning period starts early May to September and Collette \& Nauen (1983), while Gaykov \& Bakhanov (2008) reported that spawning of E. alletteratus occurs from April to November in eastern and western Atlantic. In the present study no samples were collected during May (closed season) and maturing females were present in April which indicates that spawning may occurred in May. Different spawning periods from January till May were observed in Tropical African Coast (Chur, 1973 ; Rudomiotkina, 1986). Gaykov and Bokhanov (2008) concluded that the spawning duration may vary from 4 to 8 months depending on the area latitude. Spawning time occurs in the areas with pronounced season alternation of the northern and southern hemispheres in the opposite calendar time corresponding to the warm period of the year.

Size at sexual maturity of E. alletteratus is an important life history parameter that has been estimated in previous studies. Knowing the size at first maturity of fish helps to predicts catchable size of the fish. The size at first maturity depends on the nature of the environment in which the population of concern lives (Moyle \& Czech, 2000). The present study revealed that E. alletteratus reached its first sexual maturity at $42 \mathrm{~cm}$ fork length, which was exactly similar to that found in the Gulf of Guinea (Chur, 1973) and close to that reported for Gulf of Gabes (Hajjej et al., 2010), while in southern Spain sexual maturity is reached at $57 \mathrm{~cm}$ fork length (Rodriguez-Roda, 1966). This difference in maturity size may relate to the environmental condition which induced phenotypic flexibility in fishes which may change size at maturity (Ishida et al., 1993; Cox and Hinch, 1997; Pyper et al., 1999; Wertheimer et al., 2004). Immature fishes were abundant in the catch during the present study and the length at first capture was estimated as 32cm (Elhaweet et al., 2013) i.e. less than the length at first maturity suggesting many fishes could not get chance to spawn even once. The smallest mature size of E. alletteratus female and male was $33 \mathrm{~cm}$ and 38 $\mathrm{cm}$ respectively which is shorter than what were reported in Tunisian water by Hajjej et al. (2010) for female and male as 38.7 and $39.4 \mathrm{~cm}$ respectively and Hattour (2000) as $40 \mathrm{~cm}$ and $41 \mathrm{~cm}$ respectively, while Diouf, (1980) determined that samples at $60 \mathrm{~cm}$ of length were fully mature in Senegal. These different between current study and other previous studies may be due to the negative effect of exploitation and mechanism of compensation which affect changes in size of maturation (Walker \& Ellis, 1998).

The Length weight relationship is used to describe mathematic model between weight and length (Wootton, 1990). It is an important biological factor which helps in the study gonad development. In the present study; length weight relationship of E.alletteratus was calculated by allometric growth equation, the value of $\mathrm{b}$ for combined sex was found to be 2.64 and for females samples 2.6 while for males samples 2.72, which show negative allometric growth equation $(b<3)$, while it was expressed as 3.125 for immature samples (positive allometric growth) which reflects better growth in weight by length for immature fishes. Length weight relationship was the subject of many studies in Mediterranean Sea; the b value of the present study is similar to that obtained in Aegen Sea and from Eastern Mediterranean Sea by Kahraman and Oray (2001) and in Levantin basin by Kahraman and Alicli (2007). 
But it is slightly less than that obtained in North Tunisia and from South Tunisia, Zarzis by Hajjej et al. (2011).These differences could be due to the sampling procedure, namely size and length range or related to seasonal reproduction or feeding activities or using data not derived from all seasons in equal proportions (Wootton, 1990).

In fisheries science, the condition factor is used in order to compare the condition fitness or well being of fish. It is based on the hypothesis that heavier fish of a particular length are in a better physiological condition (Bagenal, 1978), also influences the reproductive cycle in fish (Welcome, 1979) and could use as an indicator of physiological state of the fish in relation to its welfare (Le Cren, 1951). It also provides information when comparing two populations living in certain feeding density, climate and other conditions (Weatherley, 1972; Ricker, 1975; Weatherly and Gills 1987). The condition factor of E. alletteratus showed steady increase from January to April then suddenly dropped in June and July (spawning season); it probably related to energy available used for reproduction. The condition factor was increasing with the increasing of fish length less than $42 \mathrm{~cm}$ (i.e. immature fishes) and then decreased with increasing the length. Bakare (1970) and Fagade (1979) stated that condition factor decreases with increase in length.

Reproductive parameters such as sex ratio and size at first maturity are of great value in fishery prediction and formulation of management measures (Bal and Rao, 1984). The results revealed that management plan is necessary for this important species in the Egyptian Mediterranean water to catch more mature fishes than immature one.To ensure sustainability of this species, applying management measures is recommended. Minimum size at capture fishes should be more than $42 \mathrm{~cm}$ and the present closed season should extend from May to July for increasing the possibilities of spawning. Elhaweet et al. (2013) during the population dynamics study of E. alletteratus in the present study area have recommended to increase the length at first capture to reach $44 \mathrm{~cm}$.

\section{CONCLUSION}

The biological parameter of E. alletteratus in Eastern Coast of Alexandria, Egypt, has been studied and revealed that immature fishes are more abundant in the catch than mature ones.First sexual maturity estimation indicates that $50 \%$ of the samples reached their first sexual maturity at length $46 \mathrm{~cm}$, while the mean length at capture was 32cm which realize the important of management plan to overcome the overfishing situation in the off Alexandria population. Extending the closed season to July and increasing the length at capture to $44 \mathrm{~cm}$, is recommended for enhancing the chance of spawning at least once during its life.

\section{REFERENCES}

Andaloro, F., Vivono, P., Campagnolo, S., Pipitone, P., Potoschi, A., Mandich, A. and Marino, G. (1998). Biologia e pescadell' alletterato, Euthynnus alletteratus, (Rafinesque 1910) neimarisiciliani. Biol. Mar. Medit. 5(3): 290-299.

Bagenal, T.B. (1978). Aspects of fish fecundity. In: S.D.Gerking (Ed) Ecology of Freshwater fish Production. Blackwell Scientific Publications, Oxford: pp. 75101. 
Bakare, O. (1970). Bottom Deposits as Food of Inland Fresh Water Fish. In: Kainji, A Nigerian man-made lake. S.A. Visser, (Ed.), Kanji Lake Studies Vol. 1.Ecology Published for the Nigerian Institute.

Bal, D.V. and K.V. Rao, (1984). Marine fisheries. Tata McGraw-Hill Publishing Company, New Delhi, pp. 51-73

Belloc, G. (1955). Les thons de la Méditerranée. Deuxième note: Thonine et Bonite. FAO Proc. Gen. Fish. Counc. Medit., 3(52): 471-486.

Cayré, P. M. and Diouf, T. (1983). Estimating age and growth of little tunny, Euthynnus alleteratus, off the coast of Senegal, using dorsal fin spine sections. U.S. Department of Commerce, NOAA. Tech. Rep., NMFS, 8: 105-110.

Clay, D. (1991). Atlantic bluefin tuna (Thunnus thynnus).A review. Inter-American Tropical Tuna Commission Special Report, 7: 89-180.

Cox, S. P., Hinch, S. G. (1997), Changes in size at maturity of Fraser River Sockeye salmon (Oncorhyn chusnerka) (1952-1993) and associations with temperature. Canadian Journal of Fisheries and Aquatic Sciences, 54: 11591165.

Chur, V. (1973). On some biological characteristics of little tuna Euthynnus alletteratus Rafinesque, 1810 in the eastern part of tropical Atlantic. Collect. Vol. Sci. Pap. ICCAT, 1:489-500

Diouf, T. (1980). Pêcheetbiologie de trios Scombridae exploités au Sénégal: Euthynnus alletteratus, Sarda sarda et Scomberomorus tritor. Thèse de doctorat 3ème cycle, Université de Bretagne Occidental, France. 159 pp.

Elhaweet, A., Sabry, E. and Mohamed, H.(2013).Fishery and Population Characteristics of Euthynnus alletteratus (Rafinesque 1810) in the Eastern Coast of Alexandria, Egypt.

Fagade, S.O. (1979). Observation of the biology of two species of Tilapia from the Lagos lagoon Nigeria. Bull. Inst. Fond Afr. Nore (Ser. A), 41: 627-658.

GAFRD (2008). Annual fishery statistics report. Genera Authority for Fisheries Resource Development, Ministry of agriculture, Cairo, Egypt.

Gaykov, V.Z., Bokhanov, D.V. (2008). The biological characteristic of Atlantic black skipjack (Euthynnus alletteratus) of the eastern Atlantic ocean SCRS/2007/132 Collect. Vol. Sci. Pap. ICCAT, 62(5): 1610-1628.

Hajjej, G., Hattour, A., Allaya, H., Jarboui, O., Mourad, C. and Bouain, A.(2010). Length-weight relationships for 13 species from Gulf of Gabes (Southern Tunisia, Central Mediterranean), 9(37): 6177-6181.

Hajjej, G., Hattour, A., Allaya, H., Jarboui, O. and Bouain, A. (2009). Sex-ratio, relation taille-masse et coefficient de condition de la thonine commune Euthynnus alletteratus (Rafinesque, 1810) des cotes tunisiennes. Bulletin de l’Institut National des Sciences et Technologie De la Mer, 36: 39-44.

Hajjej, G., Hattour, A., Allaya, H., Jarboui, O., Mourad, C. and Bouain, A. (2011). Biometry, Length-length and Length-weight relationships of little tunny Euthynnus alletteratus in the Tunisian Waters. Journal of Fisheries and Aquatic Science, 6(3): 256-263.

Hattour, A. (2000). Contribution à l'étude des poisons pélagiques des eauxtunisiennes. Thèse de doctorat en sciences biologiques, Faculté des sciences de Tunis, Tunisie, 344 pp.

Ishida Y., Ito S., Kaeriyama M., McKinnell S., Nagasawa K. (1993). Recent changes in age and size of chum salmon (Oncorhyn chusketa) in the North Pacific Ocean and possible causes, Canadian Journal of Fisheries and aquatic Sciences, 50: 290-295. 
Junk, W.J. (1999). The flood pulse concept of large rivers: learning from the tropics. Large Rivers 11(3):261-280.

Kahraman, A.E., Alicli, T.Z., Akayli, T. and Oray, I.K.(2008).Reproductive biology of little tunny, Euthynnus alletteratus (Rafinesque, 1810), from the north-eastern Mediterranean Sea. Journal Applied of Ichthyology, 24: 551-554.

Kahraman, A.E. (2005).Preliminary investigations on Atlantic little tunny (Euthynnus alletteratus Raf., 1810) in the eastern Mediterranean Sea. Col. Vol. Sci. Pap. ICCAT, 58(2): 502-509.

Kahraman, A.E. and Oray, I.K. (2001). The determination of age and growth parameters of Atlantic little tunny (Euthynnus alletteratus Raf., 1810) caught in Turkish waters. SCRS/00/49.Col. Vol. Sci. Pap. ICCAT, 52: 719-732.

Kahraman, A. (2005). Preliminary investigations on Atlantic black skipjack (Euthynnus alletteratus Raf., 1810) in the eastern Mediterranean Sea. SCRS/2004/072.Col. Vol. Sci. Pap. ICCAT, 58(2): 502-509

Kahraman, A.E and Alicli, T.Z. (2007). Sexual maturity of littletunny, Euthynnus alletteratus, in the North-Eastern Levantine Basin. Istanbul University, Fisheries Faculty, Laleli, Istanbul, Turkey. Rapp. Comm. int. Mer Médit., 38

Kahraman, A.E., Alıçlı, T.Z., Akaylı, T., and Oray, I.K.( 2008). Reproductive biology of little tunny, Euthynnus alletteratus (Rafinesque), from the northeastern Mediterranean Sea. J. Appl. Ichthyol. 24(5): 551-554.

Landau R. (1965). Determination of age and growth rate in Euthynnus alletteratus and Euthynnus affinis using vertebrae. Commission International epourl' Exploration Scientifique de la mer Méditerranée 8: 241-244.

Le Cren, E. (1951). The length-weight relationship, seasonal cycle in gonad weight and condition in the perch (Perca ${ }^{-}$u-viatilis). J. Anim. Ecol. 20: 201-219.

Macías, D., Lema, L., Gómez-Vives, M.J., Ortiz, J.M. de Urbina and de la Serna, J.M. (2006). Some biological aspects of small tunas (Euthynnus alletteratus, Sarda sarda \& Auxis rochei) from the South Western Spanish Mediterranean traps SCRS/2005/103 Col. Vol. Sci. Pap. ICCAT, 59(2): 579-589.

Mendonça, A. E., Isidro, G., Menezes, M. Rui-Pinho, O., Melo and Estácio, S. (2006). New contribution to the reproductive features of blue mouth Helicolenus dactylopterus dactylopterus from the northeast Atlantic (Azores Archipelago). Scientia Marina, 70(4): 679-688.

Moyle, P.B. and Cech, j.r. (2000). Fishes An introduction to ichthyology, $4^{\text {th }}$ ed Upper Saddle River, New Jersey Prentice Hall, 612pp.

Nikolski, G.V. (1963). The Ecology of Fishes, Academic Press, N.Y, 624 pp.

Oray, I.K., Karakulak, F.S., Alıclı, Z., Ates, C. and Kahraman, A. (2005). First evidence of spawning in the eastern Mediterranean Sea preliminary results of tuna larval survey in. SCRS/2004/144 Col. Vol. Sci. Pap. ICCAT, 58(4): 13411347

Pitt, T.K. (1970). Distribution abundance and spawning season of yellow tail flounder, Limanda ferucineain the Newfound Land area of the North Week Atlantic. J. Fish Res. Bd. Canada, 27 (112): 2216-2271.

Pyper, B. J., Peterman R. M., Lapointe M. F., Walters C. J. (1999). Patterns of covariation in length and age at maturity of British Columbia and Alaska sockeye salmon (Oncorhynchus nerka) stocks. Canadian Journal of Fisheries and Aquatic Sciences, 56: 1046-1057.

Ramon, D.and Bailey, K. (1996).Spawning seasonality of albacore, Thunnus alaunga, in the South Pacific Ocean. Fishery Bulletin, 94(4): 725-733. 
Restrepo, V. (1991). Some possible bias in swordfish VPAs due sexually dimorphic growth. Collect. Vol. Sci. Pap. ICCAT, 35: 338-345.

Riker, W.W. (1975). Computations and interpretations of biological Statistics of fish populations. Bull. Fish. Res. Bd. Can., 191:201-210.

Rodriguez Roda, J. (1966). Estudio de la bacoreta, Euthynnus alletteratus (Raf.), bonito, Sardasarda (Bloch) y melva Auxisthazard (Lac.), capturedos porlasalmadrabas españolas. Invest. Pesq. 30: 247-92.

Rodriguez Roda, J. (1979). Edad y crecimiento de la bacoreta, Euthynnus alletteratus (Raf.) de la costa sudatlántica de España. Invest. Pesq. 47 (3): 397-402.

Rudomiotkina, G. P., (1986). Data on reproduction of Atlantic black skipjack in the tropical West African water. Collect. Vol. Sci. Pap. ICCAT, 25(2): 258-261.

Santamaria, N., Deflorio, M. and De Metrio, G. (2005). Preliminary study on age and growth of juveniles of sarda sarda, bloch, and Euthynnus alletteratus, rafinesque, caught by clupeoids purse seine in the southern Italian SEAS.SCRS/2004/087.Col. Vol. Sci. Pap. ICCAT, 58(2): 630-643.

Shelley, C. and Southgate, P. (1988).Reproductive periodicity and morphometry of Hippopus hippopus and Tridacna crocea. Giant clams in Asia and the Pacific. ACIAR monograph no. 9. 274pp.

Shelley, C. and Southgate, P. (1988) Reproductive periodicity and morphometry of Hippopus hippopus and Tridacna crocea. In Giant clams in Asia and the Pacific, Copland JW, Lucas JS (eds). Australian Cent. For International Agricultural Research: Canberra; 86:8.

Sun, C.L.; Wang, W.J. and Su-Zan, Y. (2005). Reproductive biology of the female yellowfin tuna Thunnus albacares in the western Pacific Ocean, 15 pp. Western and Central Pacific Fisheries Commission Scientific Committee, Noumea

Sylva, D. and Rathjen, W. (1961). Life History Notes on the Little Tuna, Euthynnus alletteratus, from The Southeastern United States. Bull. Mar. Scie. Gulf and Caribbean, volume II.

Valeiras, J. and Abad, E. (2006). International commission for the conversation of the Atlantic tuna chapter 2. Atlantic black skipjack

Valeiras, J. and Abad, E. (2007). ICCAT Field Manual. Chapter 2. Description of Species. 2.1 Species Directly Covered by the Convention. 2.2.11. Small tuna

Valeiras, X., and Macías, D. (2008). Age and growth of Atlantic little tuna (Euthynnus alletteratus) in the western Mediterranean sea. Collect. Vol. Sci. Pap. ICCAT, 62(5): 1638-1648

Walker, P.A. and Ellis, J(1998). Ecology of rays of the north-eastern Atlantic. In: Biology of skates. Proceedings of the Biology of Skates Symposium (New Orleans, 1996), pp 7-29, Princeton Press, New Orleans.

Weatherley, A. H. (1972). Growth and ecology of fish populations. Acad. Press. London and New York, 443pp.

Weatherly, A.H. and Gill, H.S. (1987): The biology of fish growth, London, academic Press, pp.433-443.

Welcome, R.L. (1979). Fisheries Ecology of Flood Plain Rivers. Longman Press, London, 317pp.

Wertheimer, A. C., Heard W. R., Maselko J. M., Smoker W. W. (2004). Relationship of size at return with environmental variation, hatchery production, and productivity of wild pink salmon in Prince William Sound, Alaska: does size matter? Reviews in Fish Biology and Fisheries, 14: 321-334.

Wootton, R.J. (1990). Ecology of teleost fishes chapman and hall, London. 
Wu, C.L. and Kuo, C.L. (1993). Maturity and fecundity of albacore from the Indian Ocean. Journal of the Fisheries Society of Taiwan, 20(2): 135-152.

\section{ARABIC SUMMARY}

بيولوجية تكاثر سمكة البلاميطة Euthynnus alletteratus (Rafinesque 1810 في الساحل الثرقي للاسكندرية - مصر

$$
\begin{aligned}
& \text { حسين محمد ـ علاء الدين الحويط ـ عصام صبري } \\
& \text { الاكاديمية العربية للعلوم و التكنولوجيا، الاسكندريطية، مصر. }
\end{aligned}
$$

تعد سمكة البلاميطة من الاسماك الهامة تجاريا في الساحل الشرقي للبحر الابيض المتوسط وبدراسة

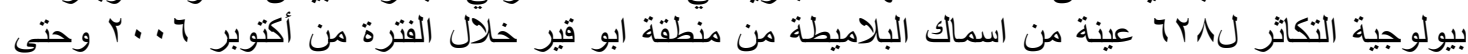

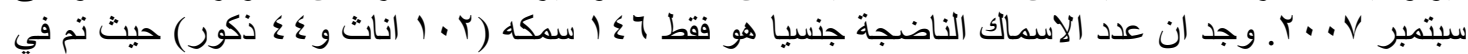

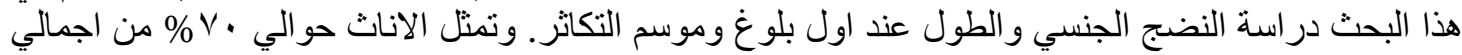

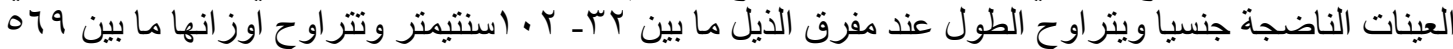

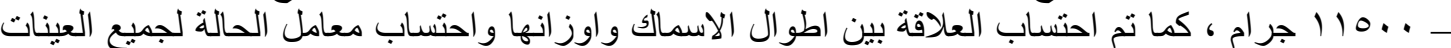

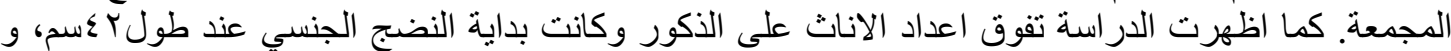

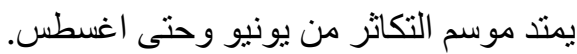

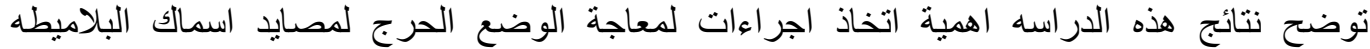

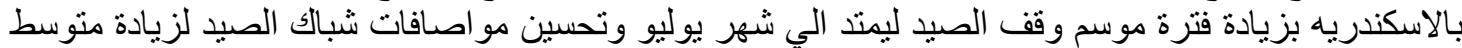
طول المصيد الي 4 ـسم حتي تسطيع الاسماك ان تبيض ولو لئ مره واحده في حياتها. 